\title{
KIMBERLITE CARBONATES: A CARBON-OXYGEN STABLE ISOTOPE STUDY
}

KIRKLEY M.B., SMITH H.S. and GURNEY J.J.

Geochemistry Department, University of Cape Town, South Africa

Wide variations in $\delta 13 \mathrm{C}$ and $\delta 18_{0}$ values of kimberlite carbonates have been reported by several workers (e.g. Kobelski et al., 1979). Some of these variations are interpreted here to be the result of primary magmatic fractionation processes. 0thers are the result of secondary mixing and exchange processes.

\section{Standard of Comparison}

Fresh hypabyssal kimberlite, that is representative of pipes in the Kimberley District of South Africa, is readily avallable from the Wesselton mine. Hence the Wesselton kimberlite was chosen as a standard for comparison with other kimberlite occurrences. Carbonates from the Wesselton kimberlite define the carbon and oxygen isotope fields shown in Figs. 1, 2 and 3 where the isotope compositions of carbonates from other occurrences are illustrated. Wesselton samples containing significant quantities ( $>1$ vol\%) of carbonate as a replacement product in microxenoliths have been excluded from the suite because the isotopic composition of oxygen in this type of carbonate $c$ an be shown to be contaminated by oxygen from the precursor minerals.

\section{Isotope Contamination by Host Rock Assimilation}

Carbonates from Group II (micaceous) kimberlites display a range of $813 \mathrm{C}$ and $\delta 180$ values that flank the Wesselton field and extend to values approaching those of sedimentary carbonates (Fig. 1). Carbonates from Finsch, Bellsbank and Swartruggens have ${ }^{13} \mathrm{C}$ - and ${ }^{18} \mathrm{O}$-enriched isotope signatures relative to the Wesselton field. These three Group II kimberlites intrude the thick Precambrian Chuniespoort Group dolomites (Transvaal System). Carbonate from a Group I (non-mic aceous) kimberlite that intrudes dolomite, the Toxteth occurrence near Kuruman, was found to be similarly enriched in ${ }^{13} \mathrm{C}$ and ${ }^{18} \mathrm{O}$. Assimilation of sedimentary carbonate host rock has

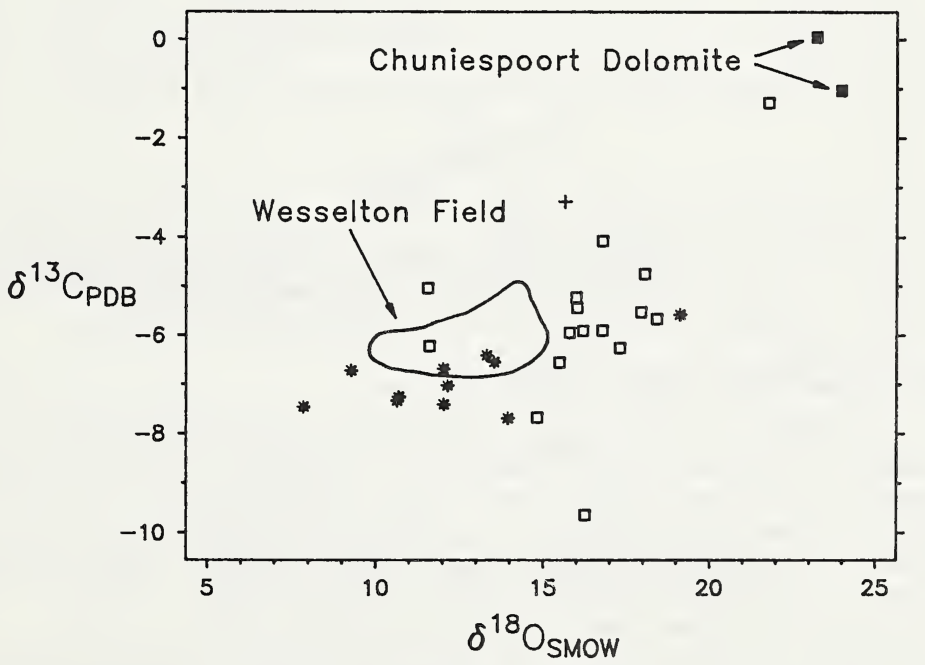

Figure 1. Stable isotope composition of carbonates from Group II kimberlites. Squares represent carbonates from Finsch, Bellsbank and Swartruggens. The cross represents carbonate from the Group I Toxteth occurrence. Stars represent carbonates from Group II kimberlites which do not intersect dolomite. 
apparently allowed ${ }^{13} \mathrm{C}$ and 180 enriched $\mathrm{CO}_{2}$ to mix with kimberlite volatiles thus changing the stable isotope compositions of kimberlite groundmass carbonate. One sample from the Newlands kimberlite, an occurrence which does not intersect dolomite, plots with the Finsch group. This sample may be 180 enriched as a result of low temperature meteoric water alteration.

\section{Isotope Fractionation Through Magmatic Differentiation}

Carbonates from the Benfontein Middle sill have carbon and oxygen isotope compositions that overlap those from Wesselton. Lower sill carbonates however are relatively depleted in $18 \mathrm{O}$ and enriched in ${ }^{13} \mathrm{C}$ such that they exhibit isotopic signatures similar to those of carbonatite carbonates (Fig. 2). The isotopic trend defined by Middle sill/Lower sill carbonates is similar to that which developed through differentiation of the carbonatites of Laacher See, West Germany (Taylor et al, 1967). $\mathrm{TiO}_{2}$ enrichment in Lower sill groundmass titanomagnetites is consistent with the hypothesis that the Lower sill represents a later differentiate of the Benfontein magma relative to the Middle sill. These data support the hypothesis that kimberlites can differentiate to carbonatitic compositions in terms of carbon and oxygen isotope values.

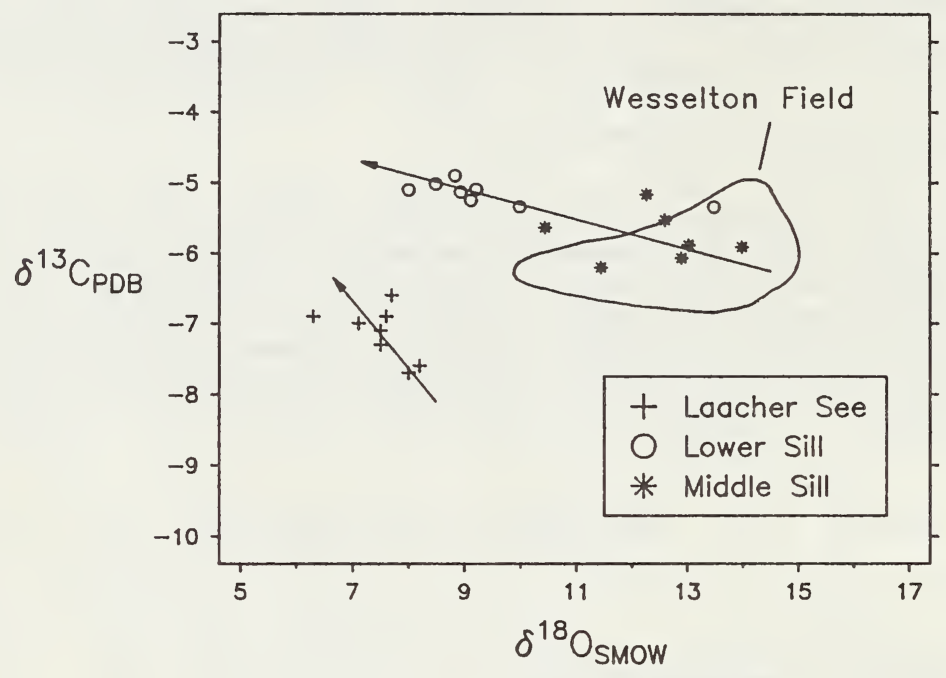

Figure 2. $\delta 1{ }^{3} \mathrm{C}-\delta 18_{0}$ relationship between carbonates from the Middle sill and Lower sill at Benfontein, compared with Laacher See carbonatites (Taylor et al., 1967). Arrows indicate differentiation trends.

\section{Isotope Fractionation Between Vapor and Liquid}

Carbonates with isotope compositions similar to those at Wesselton are conspicuously absent in the Monastery kimberlite. Carbonates from the Monastery kimberlite groundmass and from carbonatized xenoliths have isotopic signatures that are ${ }^{13} \mathrm{C}$ enriched by 2 to 4 per mil relative to the Wesselton average (Fig. 3 ). Such $13 \mathrm{C}$ enrichment may be a function of ${ }^{13} \mathrm{C}$ being fractionated into $\mathrm{CO}_{2}$ vapor, as has been shown to occur in basalt systems (Pineau et al., 1976; Javoy et al., 1978), and suggests that the Monastery volatiles were particularly enriched in $\mathrm{CO}_{2}$.

Calcite inclusions found in ilmenite megacrysts from Monastery have ${ }^{13} \mathrm{C}$ enriched signatures similar to the kimberlitic calcites. Petrographically these inclusions appear to be primary and armoured against alteration by the enclosing megacryst. The isotopic similarities between these carbonate occurrences at Monastery imply that the kimberlite and megacryst systems had similar $\mathrm{CO}_{2}-\mathrm{rich}$ compositions. This supports a close genetic relationship between kimberlite and megacryst liquids and implies that $\mathrm{CO}_{2}$ enrichment is a function of the Monastery source area. 


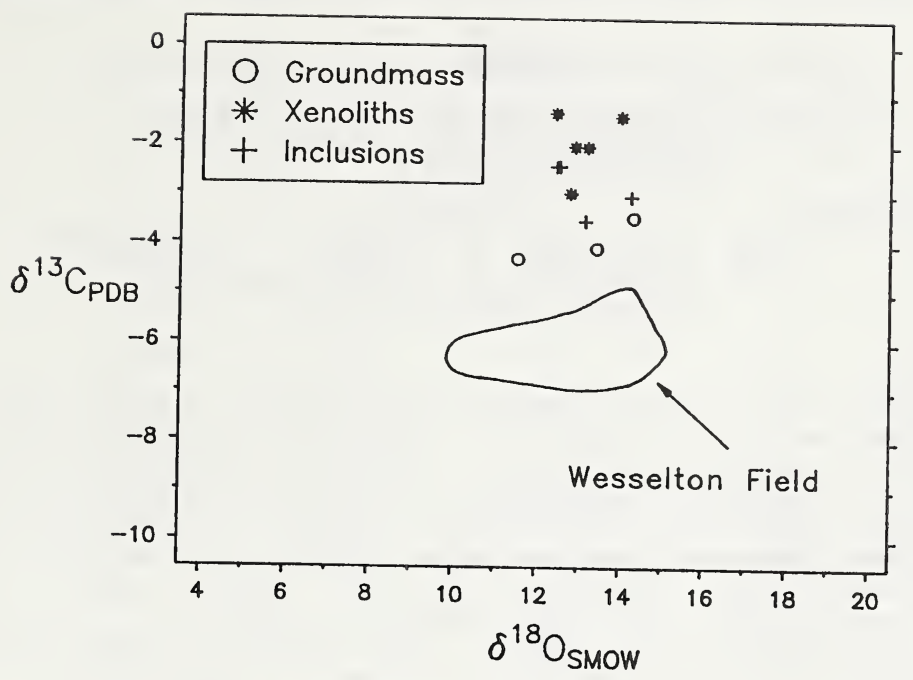

Figure 3. $\quad{ }^{13} \mathrm{C}$ enrichment exhibited by groundmass carbonate from the Monastery kimberlite, carbonatized xenoliths, and calcite inclusions in ilmenite
megacrysts.

\section{References}

JAVOY M., PINEAU F. and IIYAMA I. 1978. Experimental determination of the isotopic fractionation between gaseous $\mathrm{CO}_{2}$ and carbon dissolved in tholeitic magma. Contributions to Mineralogy and Petrology 67, 35-39.

KOBELSKI B.J., GOLD D.P. and DEINES P. 1979. Variations in stable isotope compositions for carbon and oxygen in some South African and Lesothan kimberlites. In Boyd F.R. and Meyer H.O.A. (eds.): Kimberlites, Diatremes, and Diamonds: Their Geology, Petrology, and Geochemistry; Proceedings of the Second International Kimberlite Conference Volume 1. American Geophysical Union: Washington D.C., pp 252-271.

PINEAU F., JAVOY $\mathrm{M}$. and BOTTINGA Y. 1976. ${ }^{13} \mathrm{C} /{ }^{12} \mathrm{C}$ ratios of rocks and inclusions in popping rocks of the Mid-Atlantic Ridge and their bearing on the problem of deep-seated carbon. Earth and Planetary Science Letters 29, 413-421.

TAYLOR H.P., FRECHEN J. and DEGENS E.T. 1967. Oxygen and carbon isotope studies of carbonatites from the Laacher See District, West Germany and the Aino District, Sweden. Geochimica Cosmochimica Acta 31, 407-430. 